\title{
Effect of the 1995-1996 bleaching event on polyp tissue depth, growth, reproduction and skeletal band formation in Montastraea annularis
}

\author{
J. M. Mendes*, J. D. Woodley \\ Department of Life Sciences, University of the West Indies, Mona, Kingston 7, Jamaica
}

\begin{abstract}
Polyp tissue depth, skeletal extension rate, reproduction and density band formation were studied in 15 colonies of Montastraea annularis from October 1994 to September 1997 as part of a long-term field study. With the commencement of a bleaching event in September 1995, the effects of bleaching on these biological parameters were examined. Bleaching affected all the parameters investigated, but the speed of recovery of each parameter to pre-bleaching values differed. Tissue depth recovered the fastest, within 4 to $8 \mathrm{wk}$ of regaining normal pigmentation. Once pigmentation and tissue depth had recovered, skeletal growth resumed at its pre-bleaching rate. Reproduction took the longest to recover and reproductive failure occurred in severely bleached colonies 1 yr after bleaching. Even after $2 \mathrm{yr}$, reproductive output remained reduced in previously bleached colonies when compared with previously unbleached ones, although all colonies had successfully completed gametogenesis and spawning. Among the reproductive parameters measured, gonad size recovered faster than the number of gonads per polyp (i.e. polyps produced a smaller number of full-sized gonads 2 yr after bleaching). In all colonies, bleached and unbleached, the 1995 annual high-density (HD) band, which formed at the time of the bleaching event, appeared more prominent and in some cases wider than the HD bands for the years that preceded and succeeded bleaching. Bleaching reduced skeletal extension rate, and the HD band that formed at the time of the bleaching event was most pronounced in colonies in which skeletal extension rate was reduced for the longest period of time (i.e. severely bleached colonies). In 1996, the year following the bleaching event, colonies that did not complete gametogenesis (i.e. severely bleached colonies) produced no distinct HD band, while those that completed gametogenesis (i.e. mildly bleached colonies) produced a distinct HD band. These findings suggest that an inverse relationship between skeletal extension rate and HD band prominence may occur in Montastraea annularis, and that the failure of severely bleached colonies to produce a HD band in 1996 might be related, not to bleaching, but rather to the lack of gonad development and spawning in these colonies.
\end{abstract}

KEY WORDS: Montastraea annularis · Coral bleaching · Skeletal density banding · Skeletal extension rate $\cdot$ Reproduction $\cdot$ Polyp tissue depth

\section{INTRODUCTION}

Coral bleaching is the loss of coloration in live corals that results from the loss of symbiotic zooxanthellae within the corals and/or a reduction in photosynthetic pigment within the zooxanthellae (Hoegh-Guldberg \&

*E-mail: jmendes@uwimona.edu.jm
Smith 1989, Glynn 1993, Fitt \& Warner 1995, Brown 1997). If the coral tissues lack pigment of their own, as is often the case, the white skeleton shows through. Bleaching occurs in response to environmental stress such as changes in salinity, temperature and light levels (including ultraviolet light) as well as exposure to air and human disturbances (review in Glynn 1993). Most recently bleaching in the temperate coral Oculina patagonica has been found to result from infection 
by the bacterium Vibrio shiloi at elevated sea temperatures (Kushmaro et al. 1996). The large-scale, mass bleaching events, which have occurred around the world in the last 20 yr (i.e. in 1979-1980, 1982-1983, 1986-1987, 1991，1995-1996 and 1997-1998), have been linked to increases in seawater temperature resulting from increased El Niño-Southern Oscillation activity and global warming (e.g. Williams \& BunkleyWilliams 1990, Glynn 1993, Brown 1997, Huppert \& Stone 1998).

Few studies have considered the effect of bleaching on coral tissue, reproduction, growth and banding. With respect to coral tissue, bleached corals have been found to have lower tissue biomass (Porter et al. 1989, Fitt et al. 1993) as well as lower lipid, protein and carbohydrate contents (Glynn et al. 1985, Szmant \& Gassman 1990) when compared to unbleached corals. The gastrodermis of bleached corals is also disrupted by the loss of zooxanthellae, with cells containing degraded zooxanthellae becoming necrotic (LeTissier \& Brown 1996) or detaching from the gastrodermal layer (Gates et al. 1992, Brown et al. 1995), and areas formerly containing zooxanthellae becoming filled with mucus (Hayes \& Bush 1990). In the only study conducted on the effect of bleaching on reproduction in Montastraea annularis, Szmant \& Gassman (1990) investigated 6 colonies that bleached in October 1987 and found that, of the 3 colonies that remained bleached for $7 \mathrm{mo}, 1$ did not initiate gametogenesis while the other 2 started (but were unable to complete) gametogenesis in the following year. In contrast, the 3 colonies that had recovered from bleaching within 7 mo were all able to follow a normal gametogenic cycle. Additionally, bleaching has been found to stop or significantly reduce skeletal growth in corals (as indicated by skeletal extension; Jokiel \& Coles 1977, Coles \& Jokiel 1978, Porter et al. 1989, Goreau \& Macfarlane 1990, Leder et al. 1991, Tudhope et al. 1992). The only study to examine the effects of bleaching on skeletal banding (Leder et al. 1991) found in a Montastraea annularis colony which had been bleached for 10 to 12 mo that the growth rate in the year following the onset of bleaching was only $37 \%$ of the rates in pre-bleaching years (annual growth increments were measured from the lower surface of high-density [HD] bands; nomenclature of Dodge et al. 1992). While the bleached colony did not have a lowdensity (LD) band in 1988 (the year following bleaching), it is not known whether the colony formed a HD band in 1988 since the colony was sampled on a date (August 24, 1988) close to the time HD band formation normally begins (Leder et al. 1991).

The aim of the work presented here was to determine the effects of bleaching on colonies of Montastraea annularis that had been studied during the year preceding the onset of the bleaching event, and for which the annual variation in polyp tissue depth, growth, reproduction and skeletal banding were already ascertained. Consequently, the changes in these parameters that were attributable to bleaching, and the duration of the colonies' recovery to their prebleaching condition, could readily be determined. This differs from previous investigations into the effects of bleaching and skeletal growth (Porter et al. 1989, Hayes \& Bush 1990, Szmant \& Gassman 1990, Leder et al. 1991, Tudhope et al. 1992, Fitt et al. 1993, Brown et al. 1995) which began only after bleaching had started.

\section{MATERIALS AND METHODS}

Study site and sampling methods. This study was conducted at 2 reef locations (Drunkenmans Cay and South East Cay) within the Port Royal Cays (Fig. 1), a collection of 8 small coral islets on Jamaica's southern shelf, adjacent to the capital city of Kingston.

Fifteen large (ca. 0.5 to $2 \mathrm{~m}^{2}$ ) columnar colonies of Montastraea annularis located at a depth of approximately $5 \mathrm{~m}$ on the Port Royal Cays were stained with Alizarin red S bone stain (Lamberts 1978). Five colonies at Drunkenmans Cay were stained in August 1994 and the remaining 10 (5 each at Drunkenmans and South East Cays) in April 1995. The stained colonies were sampled repeatedly over the period October 1994 to September 1997. A $4 \mathrm{~cm}$ diameter hole saw, powered by a pneumatic drill, was used to collect short $(3$ to $5 \mathrm{~cm}$ ) cores of skeleton and tissue from the tops of coral columns within each colony. The holes left upon core removal were filled with pre-formed cement plugs to prevent bio-eroder access to the coral colonies. The initial 5 colonies were sampled at every full and new moon (i.e. approximately every $2 \mathrm{wk}$ ) from

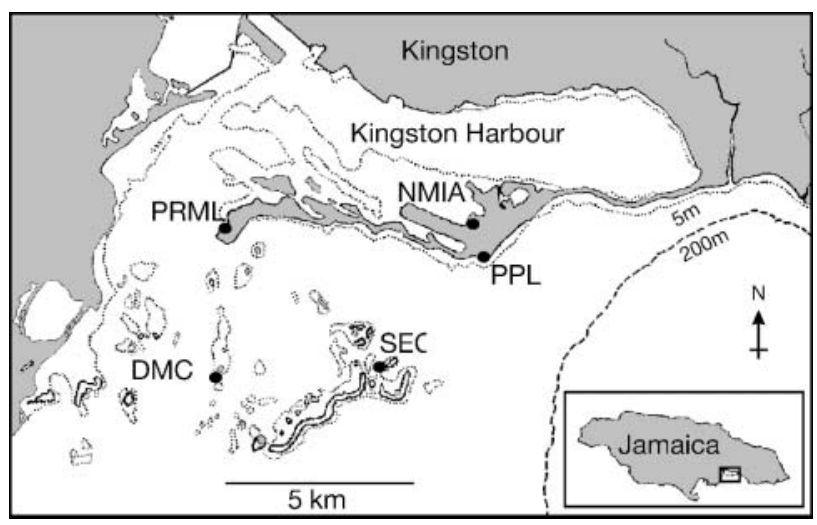

Fig. 1. Location of study site. DMC, Drunkenmans Cay site; SEC, South East Cay site; PRML, Port Royal Marine Laboratory; NIMA, Norman Manley International Airport; PPL, Plumb Point Lighthouse 
October 1994 until December 1995. The remaining 10 colonies were sampled at every full moon (i.e. approximately every month) from April 1995 until March 1996. Samples were then taken for all colonies, either monthly or bi-monthly until October 1996, and then at 1 to 6 mo intervals until September 1997.

All samples were fixed with $10 \%$ seawater formalin for $24 \mathrm{~h}$ and rinsed in running tap water for approximately $6 \mathrm{~h}$. Cores were then cut longitudinally into 2 using a rock saw with a diamond-tipped blade (Contempo Lapidary) and the portion of each core sample to be used for skeletal measurements, polyp measurements and X-radiographic studies was air-dried.

Skeletal slab measurements. A $2.5 \mathrm{~mm}$ thick slab was cut from the air-dried portion of the core sample, parallel to the growth axis, using a slow-speed diamond-wheel rock saw (Model no. 650, South Bay Technology). This slab thickness was used because it is less than the diameter of a corallite, and hence allows images of the endothecal and exothecal portions of the skeleton to be clearly visualized without being obscured by neighboring structures (Dodge et al. 1992). Each slab contained 2 dated points: the stain line (for which the time of staining was known) and the surface (for which the date of collection was known).

The slabs were scanned on a flatbed scanner (Scan Jet $6100 \mathrm{C}$, Hewlett Packard) at $10 \times$ original size, and the distance from the stain line to the growth surface was measured on the scanned image (5 measurements per slab) using SigmaScan Pro automated image analysis software (SPSS). The distances from the stain line to the surface on successive slabs were used to calculate the skeletal extension rate.

Polyp tissue depth (from the base of the polyp to the highest point of the septa) was also measured on the scanned skeletal slabs. This was possible because the fixed tissue that had dried in place within the sample core was clearly visible on the slabs. This method was selected because it yielded tissue depth values that were greater than those obtained from the measurement of longitudinal histological sections. Tissue depths of 5 polyps were measured on each slab.

$\mathbf{X}$-radiographic studies. To reveal the skeletal density bands, the slabs were X-rayed with a General Electric MVP 80 X-ray unit (using a fine focal spot and a focal distance of $102 \mathrm{~cm}$; exposure was $25 \mathrm{~mA}$ at $56 \mathrm{kV}$ ) on to Kodak AA Industrex ready pack film. The $\mathrm{X}$-radiographs of the slabs were scanned on a flatbed scanner at $10 \times$ original size. Once scanned, the distance from the most recently formed HD band to the surface was measured and the nature of the density band being formed at the surface (LD, HD or subannual, where a sub-annual band is a dense band that formed within an LD band) was recorded. From these observations the timing of HD band formation was determined. Additionally, annual extension (given by the width of the HD-LD band, i.e. the combined widths of the HD band and LD band formed during 1 year's growth) on each slab was measured for comparison with the annual skeletal extension values calculated from stain-line-to-colony-surface measurements taken from the coral slabs.

The scanned X-radiograph images were combined with the previously scanned images of the slabs using PHOTO-PAINT graphics software (V.8., Corel Corporation). An image was thus produced in which the stain line of the slab was superimposed on the X-radiograph. This allowed the density banding pattern and the number of dissepiments, which had formed subsequent to the time of staining, to be determined from the combined images.

Gametogenesis and fecundity. The portion of each core sample to be used in histological studies of reproductive structures was decalcified in $10 \% \mathrm{HCl}$. The soft tissue remaining after decalcification was washed overnight in running tap water to remove the acid and then stored in $70 \%$ ethanol (with $1 \%$ glycerol) until embedding. For each sample, tissue containing 10 to 20 polyps was dehydrated, cleared and embedded in paraffin. After this, serial transverse sections, $8 \mu \mathrm{m}$ thick, were cut from 5 approximately equally spaced levels within the polyps, between the base of the pharynx and the top of the basal gastrodermis, and then mounted on glass slides. Slides were stained with Heidenhain's azocarmine-aniline blue (Luna 1968) and examined with a compound microscope at $400 \times$.

For each sample, the slide with polyps containing the greatest expression of gonads (lower mid section of the polyp) was used to estimate coral fecundity (gonad number and size; Guzman \& Holtz 1993). The sizes (crosssectional areas) of 5 randomly chosen polyps and their gonads were measured. Images of the polyps were generated with a microscope-mounted video camera (Teachcam NTSC Rev 6.5, Video Labs) and captured using a video digitizer (Snappy video snapshot v3.0, Play). Measurements were made on captured images using SigmaScan Pro automated image analysis software.

Bleaching observations. The condition of all colonies (normal, pale or bleached; bleached colonies were white, while pale colonies were those in which the dark green/brown color was less intense than that observed in normal colonies) was recorded on all routine sampling occasions, from the onset of bleaching in September 1995 to the end of the bleaching event in April 1996. This allowed the duration and extent of bleaching of each colony to be determined. Colonies were also categorized as either severely or mildly bleached depending on the duration of bleaching.

Environmental parameters. Water temperature at Drunkenmans Cay was recorded at $5 \mathrm{~m}$ depth from 
April 1995 to December 1996 using HOBOtemp miniature data loggers with internal sensors (Onset Computer). The data loggers were deployed in opaque waterproof cases and further protected in plastic housings with holes at the side to permit water movement. This arrangement prevented radiant energy from heating the air space around the data loggers, which leads to erroneous readings (A. Szmant pers. comm.). Calibration accuracy of the sensors was tested by checking the temperature at $0^{\circ} \mathrm{C}$ with an ice bath. All sensors read within $\pm 0.12^{\circ} \mathrm{C}$ at $0^{\circ} \mathrm{C}$.

Statistical analysis. All statistical analyses were performed with STATISTICA (v.6 1998) using a significance level of $p=0.05$. All data are presented as means \pm SE and were tested for normality using the Shapiro-Wilks' $W$-statistic and by examination of normal probability plots. To assess the effects of staining and the sampling regime on skeletal extension and coral physiology, the mean annual skeletal extensions in all normal colonies (derived from the measurements of HD-LD band widths on X-radiographs) for pre- (1993) and post-staining years (1994 through 1997) were compared using a 1-way ANOVA. Polyp tissue depth was correlated (Pearson r) with the duration of bleaching. The number of dissepiments and the distance (skeletal extension) from the time of staining to the surface of each colony were also correlated (Pearson r). Pre- and post-bleaching values for polyp tissue depth, annual skeletal extension, reproductive output, gonad size and number of gonads in all colonies were compared using t-tests. A 1-way ANOVA was used to compare skeletal extension rates in unbleached, mildly and severely bleached colonies during the bleaching event. A test of parallelism (in the ANCOVA module of STATISTICA) was used to compare the slopes of the regression lines between skeletal extension and number of dissepiments in unbleached, mildly and severely bleached colonies.

\section{RESULTS}

\section{Effect of staining and sampling}

Staining and the sampling regime had no adverse effect on skeletal extension and coral physiology, with the mean annual skeletal extensions in unbleached colonies for 1993 (the pre-staining year) not being significantly different from those for 1994-1997 (the poststaining years; $F=0.554, \mathrm{df}=3,21, \mathrm{p}=0.65$ ).

\section{Bleaching observations}

Bleaching was first observed in 1995 on September 16 , the day after spawning (and $15 \mathrm{~d}$ after the mean daily water temperature had risen above $30^{\circ} \mathrm{C}$, the temperature above which bleaching generally occurs in the Caribbean; Ogden \& Wicklund 1988; Fig. 2a). No bleaching was observed just $2 \mathrm{~d}$ before, on September 14 . The mean daily water temperature remained above $30^{\circ} \mathrm{C}$ for an additional $5 \mathrm{~d}$ after the onset of bleaching. During the bleaching event, 7 of the 15 colonies did not bleach, 6 were bleached for up to 2 mo (and remained pale for an additional 1 to $3 \mathrm{mo}$; these were the mildly bleached colonies) and 2 colonies remained bleached for 4 mo (and stayed pale for an additional $3 \mathrm{mo}$; these were the severely bleached colonies). In 1995, when the bleaching event occurred, the mean daily water temperature remained above $30^{\circ} \mathrm{C}$ for a total of $20 \mathrm{~d}$ (with a maximum temperature of $30.9^{\circ} \mathrm{C}$ ); however, in 1996, when no bleaching occurred, the mean daily water temperature remained above $30^{\circ} \mathrm{C}$ for $7 \mathrm{~d}$, of which only 5 were consecutive (maximum temperature was $30.3^{\circ} \mathrm{C}$ ).

\section{Effect of bleaching on polyp tissue depth}

All colonies underwent a reduction in polyp tissue depth at the onset of the bleaching event (Fig. 2b). In unbleached colonies, however, the extent of the reduction in tissue depth during the bleaching event was not significantly different from the extent of the reduction in tissue depth during the same period of the previous year (October to December 1994; $t=0.009, \mathrm{df}=51$, $\mathrm{p}=0.99$ ). In all bleached colonies, polyp tissue depth was reduced throughout the course of the bleaching event (Fig. 2b), with polyp tissue depth being negatively correlated with the duration of bleaching $(\mathrm{r}=-0.93, \mathrm{p}<0.0001$; Fig. 3). Within 4 to $8 \mathrm{wk}$ of regaining their normal coloration, coral colonies regained their pre-bleaching size (Fig. 2b).

\section{Effect of bleaching on skeletal extension}

During the bleaching event, skeletal extension rate remained low in all bleached colonies (Fig. 2c). The duration of skeletal extension rate reduction corresponded to the length of time that the colonies remained bleached: 7 mo in severely bleached colonies, which were bleached for 4 mo and remained pale for an additional $3 \mathrm{mo}$; and $5 \mathrm{mo}$ in mildly bleached colonies, which were bleached for up to 2 mo and remained pale for 1 to 3 additional mo. The reduction in skeletal extension rate in unbleached colonies in September and October 1995 was not significantly different from the reduction in skeletal extension rate in the same colonies for the corresponding period in the previous year $(t=0.747, \mathrm{df}=8, \mathrm{p}=0.48)$. During the 

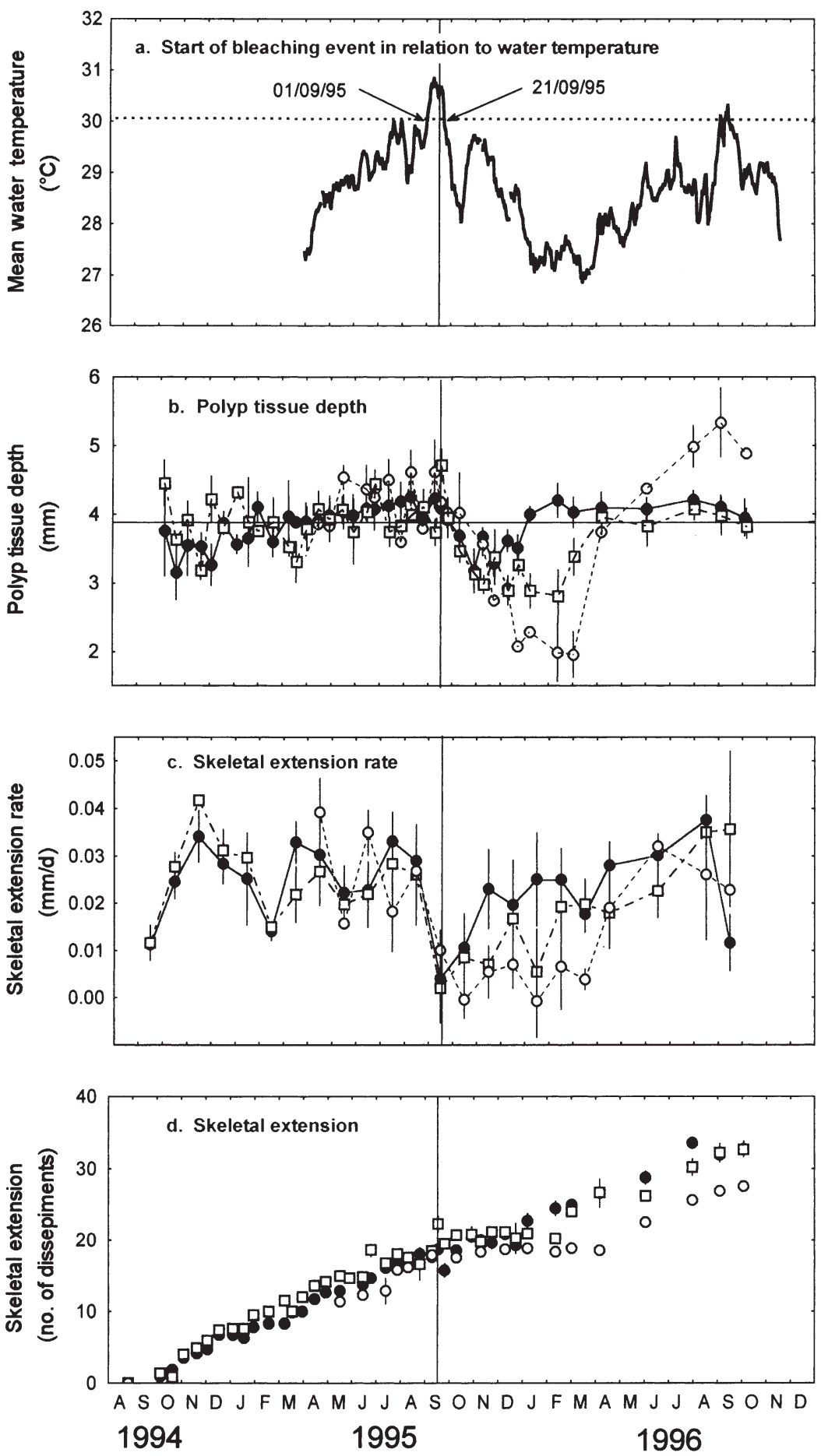

Fig. 2. Timing of bleaching event and its effect on polyp tissue depth and skeletal extension. ( $\bullet$ ) Unbleached colonies; ( $\square$ ) mildly bleached colonies; (O) severely bleached colonies; vertical line = date bleaching was first observed (16/09/95). (a) Water temperature at $5 \mathrm{~m}$ depth at Drunkenmans Cay; (b) Horizontal line = mean tissue depth September 1994 to September 1995. (c) Skeletal extension calculated from sequential stain line to surface measurements on the skeletal slabs. (d) The numbers of dissepiments for all colonies stained in April 1995 were corrected to the mean number of dissepiments present in April 1995, in colonies stained in August 1994 bleaching event, skeletal extension rates in unbleached, mildly and severely bleached colonies were significantly different $(F=$ 5.80, $\mathrm{df}=2,75, \mathrm{p}=0.005)$. Skeletal extension rates during the period prior to (September 1994 to September 1995) and after (April 1996 to September 1996) the bleaching event were not different for unbleached, mildly and severely bleached colonies $(F=0.17$, $\mathrm{df}=2,175$, $\mathrm{p}=0.85$ ).

As a result of the period of reduced skeletal extension during the bleaching event, mean annual skeletal extension for September 1995 to September 1996 (annual density bands in Montastraea annularis at Drunkenmans Cay form most frequently in September; Mendes 2002) was less in severely bleached colonies $(5.17 \pm 0.3 \mathrm{~mm})$ than in unbleached ones $(8.55 \pm 0.7 \mathrm{~mm} ;=2.67$, df $=7$, $\mathrm{p}=0.03$ ). In the year following the bleaching event from September 1996 to September 1997, there was no significant difference in skeletal extension between the colonies that had not bleached and colonies that bleached in 1995-1996 ( $t=-0.78$, df $=13, \mathrm{p}=0.45)$. There was also no significant difference between skeletal extension in September 1996 to September 1997 (the year after bleaching) and skeletal extension in September 1994 to September 1995 (the year prior to bleaching) for all colonies $(t=1.20, \mathrm{df}=28, \mathrm{p}=0.24)$.

While bleaching reduced the skeletal extension rate, it had no effect on the spacing of dissepiments. In each sample, the number

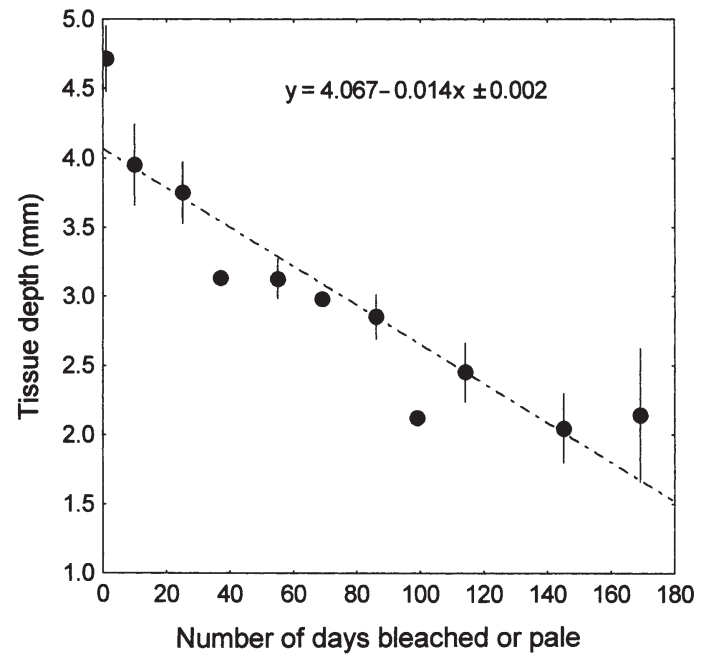

Fig. 3. Relationship between polyp depth and length of bleaching 


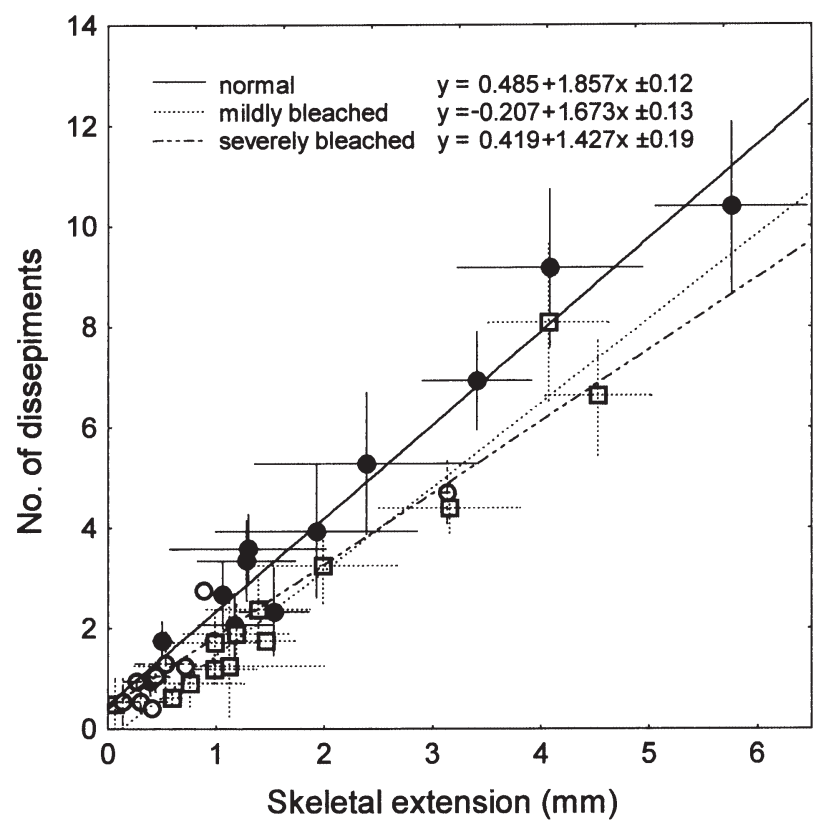

Fig. 4. Relationship between skeletal extension and number of dissepiments. (•) Unbleached colonies; ( $\square)$ mildly bleached colonies; (O) severely bleached colonies

of exothecal dissepiments formed from the start of the bleaching event to the time of collection, and the skeletal extension during the same period were strongly correlated (unbleached colonies: $r=0.97$, $p<0.000$; mildly bleached colonies: $\mathrm{r}=0.93, \mathrm{p}<0.000$; severely bleached colonies: $r=0.94, p<0.000$; Fig. 4). The slopes of the regression lines between skeletal extension and dissepiment formation (i.e. the numbers of dissepiments per $\mathrm{mm}$ of skeletal extension) in unbleached, mildly and severely bleached colonies throughout the period of bleaching were not significantly different $(F=0.85, \mathrm{df}=2,29, \mathrm{p}=0.43$; Figs. $2 \mathrm{~d} \& 4)$.

\section{Effect of bleaching on reproduction}

In 1996, the year following the bleaching event, there were reductions in reproductive output (as indicated by decreases in the percentage of polyp crosssectional area occupied by gonads) when compared to the previous year. In addition, the numbers and sizes of gonads in colonies that bleached (severely and mildly) were smaller than those in colonies that had not bleached (Fig. 5a,b,c).

In spite of the reduced gonad size and number, all 6 mildly bleached colonies completed gametogenesis and spawned in 1996. The 2 severely bleached colonies, however, did not complete gametogenesis as no gonads were observed after July and they did not spawn in 1996. In 1997 (2 yr after the bleaching event), the only pre-spawning sample (taken approximately 1 mo before spawning) was comparable to that taken about 3 wk before spawning in 1995. All colonies completed gametogenesis and spawned in 1997, but the reproductive output of the colonies that bleached still did not match that of the unbleached colonies (percent of polyp cross-sectional area in unbleached colonies: $23.6 \pm 2.6 \%$; severely and mildly bleached colonies: $12.5 \pm 3.3 \% ; t=2.59, \mathrm{df}=13, \mathrm{p}=0.022)$. In 1997, gonad size was comparable in both previously bleached and unbleached colonies (unbleached: $385 \pm 43 \mu^{2}$; severely and mildly bleached: $328 \pm 56 \mu^{2} ; t=0.87$, $\mathrm{df}=13, \mathrm{p}=0.40$ ). However, the number of gonads in 1997 was still reduced in previously bleached colonies when compared with unbleached ones (unbleached: $11.2 \pm 0.4$; severely and mildly bleached: $7.1 \pm 1.6$; $t=2.36, \mathrm{df}=13, \mathrm{p}=0.034)$.

\section{Effect of bleaching on skeletal banding pattern}

In all colonies, bleached and unbleached, the 1995 HD band which formed at the time of bleaching appeared more prominent (i.e. darker and in some cases wider) than the HD bands for the years that preceded and succeeded bleaching (see examples in Fig. 6). This effect was most pronounced in the severely bleached colonies.

In 1996, colonies that had been severely bleached produced no distinct HD band; a distinct HD band was produced, however, in mildly bleached colonies. In addition, 3 of the 6 mildly bleached colonies formed a sub-annual band in May/July (see example in Fig. 6). In 1997, normal HD and LD bands were formed in all colonies.

In all unbleached, mildly bleached and 1994-1995 severely bleached colonies in which it was possible to determine mean annual skeletal extensions from X-radiographs (using the widths of the HD-LD bands, with each annual density band consisting of $1 \mathrm{HD}$ band and 1 LD band), the values were comparable $(t=0.67$, $\mathrm{df}=42, \mathrm{p}=0.51$ ) to those determined directly from the skeletal slabs (using the stain-line to surface measurements; Fig. 6). For severely bleached colonies in 1995-1996 and 1996-1997, only stain-line to surface measurements were used to determine mean annual skeletal extensions; no HD band was formed in 1996 and it was thus not possible to determine the mean annual extension from the X-radiographs.

\section{DISCUSSION}

While bleaching affected all the coral parameters investigated (i.e. tissue depth, skeletal extension, 
reproduction and density banding), the speed of recovery of each of these parameters to pre-bleaching values differed. Tissue depth (which was adversely affected by bleaching; Fig. 2a and other studies: Porter et al. 1989, Szmant \& Gassman 1990, Fitt et al. 1993) recovered fastest, with bleached colonies in the pres-
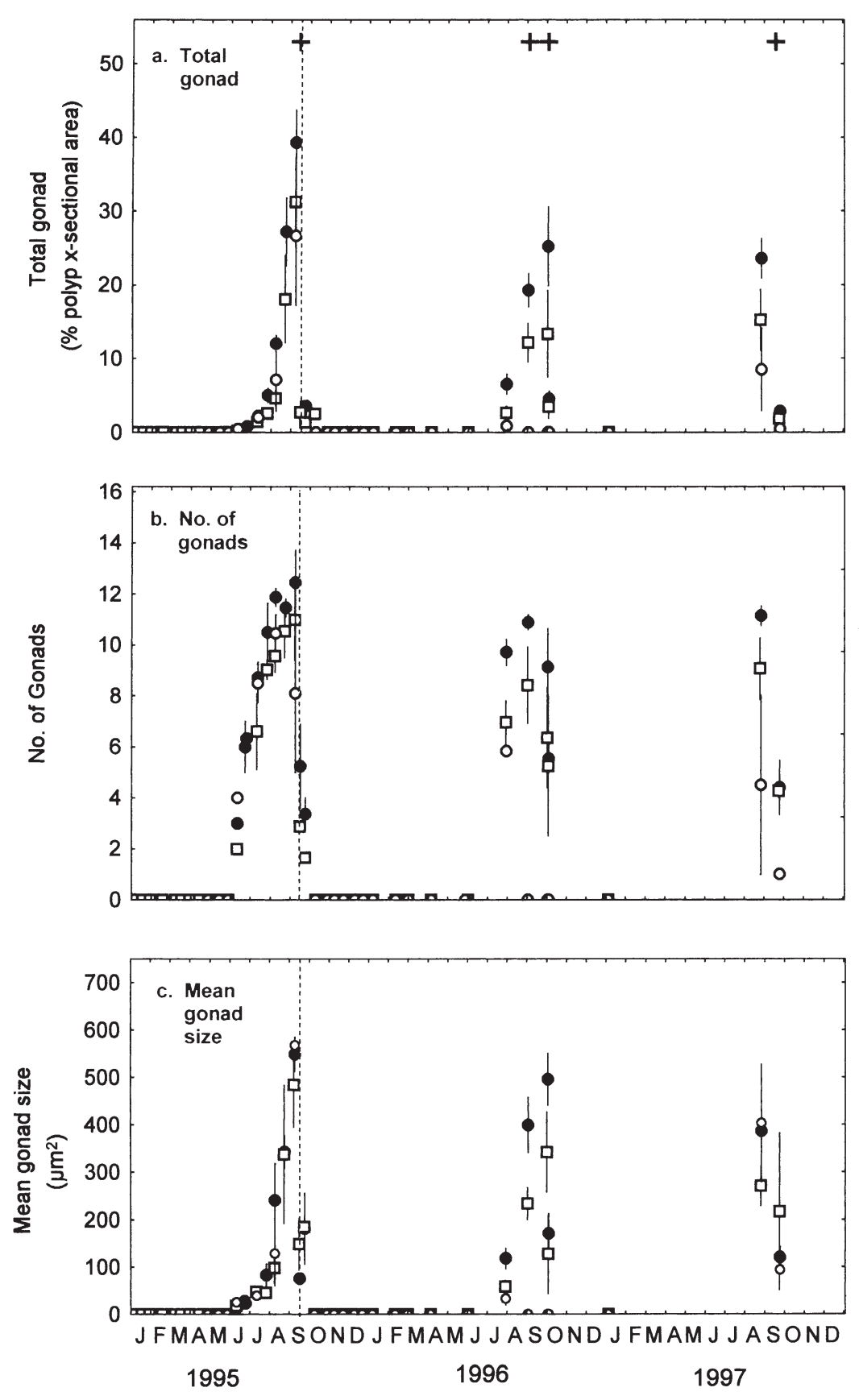

Fig. 5. Effect of bleaching on reproduction in Montastraea annularis. $(\bullet)$ Unbleached colonies; ( $\square$ ) mildly bleached colonies; (O) severely bleached colonies; (+) spawning event (the 2 spawning events in consecutive months in 1996 indicate a split spawning); vertical line = date bleaching was first observed (16/09/95) ent study regaining their pre-bleaching polyp size within 4 to 8 wk of regaining normal coloration. Fitt et al. (1993) found that, after regaining normal zooxanthellal densities, a Montastraea annularis colony still required up to $2 \mathrm{yr}$ to regenerate the tissue biomass lost during bleaching; this longer tissue depth recovery time may be because samples were collected on only 3 occasions $(5,10$ and 24 mo) after bleaching began. Our finding that polyp tissue depth changed seasonally in unbleached M. annularis colonies, with the lowest values occurring after spawning (October to December; Fig. 2a), is consistent with the finding of Fitt et al. (2000) that tissue biomass in $M$. annularis was lowest in late summer and fall.

For bleached colonies, the duration of bleaching was directly related to the extent of the reduction in tissue depth (i.e. the longer the colonies remained bleached, the smaller the polyps became, shrinking from the base up, with the basal tissue being drawn closer and closer to the surface of the colony). This strong correlation between the duration of bleaching and polyp tissue depth supports the idea that corals catabolize their own tissue when insufficient energy is provided by the zooxanthellae. Zooxanthellae provide up to $100 \%$ of their coral hosts' daily energy requirements (e.g. Muscatine 1967, Muscatine et al. 1984, Edmunds \& Spencer Davies 1986), and Szmant \& Gassman (1990) have suggested that in the absence of energy from the products of zooxanthellal photosynthesis, corals may catabolize their tissues.

Once the coral colonies regained their normal pigmentation and tissue depth, skeletal extension rates returned to those found before the bleaching event and were similar to those found in colonies that had not bleached; however, the period of reduced growth during the bleaching event meant that the annual skeletal extension for 1995-1996 was significantly less in severely bleached colonies than in colonies that had not bleached. This suggests that bleaching had no long-term effect on the post-bleaching skeletal extension rate. In the short term, however, bleaching adversely affected annual skeletal extension in Montastraea annularis (see also Leder et al. 1991), with the length of time that colonies remained bleached corresponding to the length of time that skeletal extension rate was reduced. This is consistent with the results of Goreau \& Macfarlane 


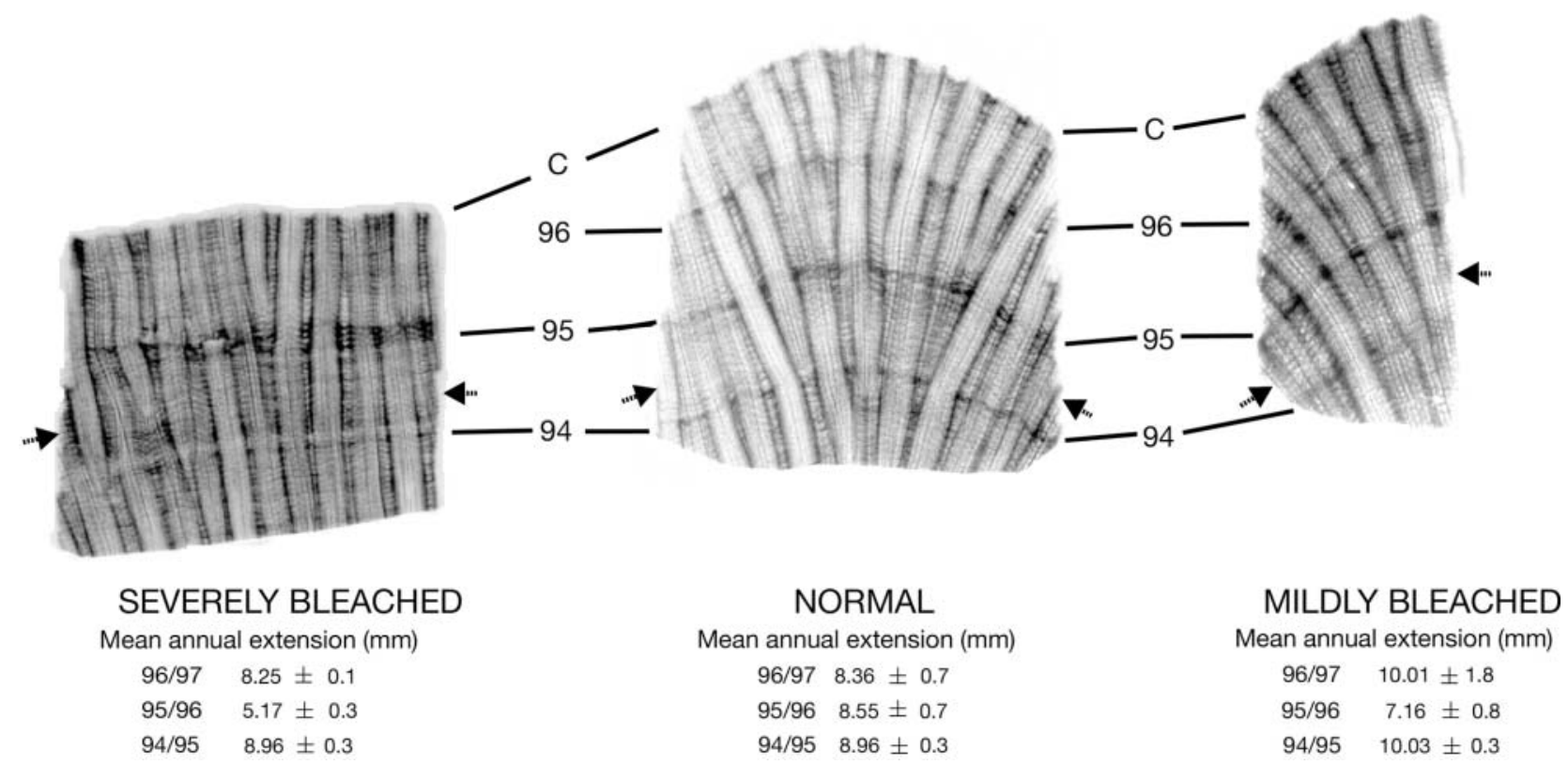

Fig. 6. Example of X-radiographs from normal, mildly bleached and severely bleached colonies showing the effect of bleaching on banding pattern. $\mathrm{C}$ = date of collection for normal and mildly bleached samples (26/09/97), and for severely bleached sample (28/08/97). 1994, 1995 and 1996 = annual HD (high density) bands. Arrows = position of stain lines. Mean annual extension calculated directly from stain line to surface measurements on the skeletal slabs, from September of one year to September of the following year

(1990) and Tudhope et al. (1992), who found a near cessation of growth in $M$. annularis and Porites colonies, while the colonies were bleached or recovering from bleaching, respectively. Bleaching had no effect on the distance between exothecal dissepiments. While bleached colonies added fewer exothecal dissepiments to their skeletons than unbleached ones, unbleached, mildly and severely bleached colonies all formed the same number of dissepiments per mm of skeletal extension.

The parameter that took the longest to recover was reproduction. Mildly bleached colonies completed gametogenesis and spawned in 1996, but severely bleached colonies were not able to complete gametogenesis and spawn until 1997, 2 yr after the bleaching event. These findings are consistent with those of Szmant \& Gassman (1990), where Montastraea annularis colonies that remained bleached for 8 mo were unable to complete gametogenesis, while those that recovered from bleaching within 8 mo completed gametogenesis. Our results and those of Szmant \& Gassman (1990) suggest that the effect of bleaching on reproduction depends on the duration of bleaching and, by extension, the length of time available after recovery from bleaching before the next bout of gametogenesis begins. A long period of time was also required for reproductive output to recover after bleaching, with the reproductive output in 1997 of colonies which bleached in 1995 being less than that of colonies that did not bleach. Of the reproductive para- meters measured, gonad size recovered faster than the number of gonads per polyp. In 1997, gonad sizes in previously bleached colonies were comparable with those in unbleached colonies, but colonies that had bleached still had fewer gonads than their unbleached counterparts. Similar long-term negative effects on reproductive output have been found to result from other stresses to coral (e.g. 39 mo after an oil spill, gonads in Siderastrea siderea were significantly smaller at oiled reef sites than at unpolluted sites; Guzman \& Holst 1993). The reduced reproductive output in previously unbleached colonies in 1996, when compared to 1995 , was probably the result of the participation of 2 unbleached colonies in a split spawning event in 1996 and the division of their reproductive output between the 2 spawnings of that year (Fig. 5a; Mendes \& Woodley 2002).

In all colonies, the 1995 HD band, which formed at the time of the bleaching event, appeared more prominent (i.e. darker and in some cases wider) than the HD bands for the years that preceded and succeeded bleaching. The longer the period in which there was a reduced skeletal extension rate, the more prominent the HD band formed (e.g. the darkest and widest HD bands were formed in the severely bleached colonies in which skeletal extension rate was reduced for the longest period of time). The possibility therefore exists that an inverse relationship between skeletal extension rate and HD band prominence may occur in Montastraea annularis. This suggestion is supported by 
previous reports of slower annual growth rates resulting in increased skeletal densities (Scoffin et al. 1992, Lough \& Barnes 2000), and of LD bands coinciding with periods of highest skeletal extension rates in corals (Guzman \& Tudhope 1998). Additionally, while unbleached and mildly bleached colonies that completed gametogenesis in 1996 formed distinct 1996 HD bands, no distinct $1996 \mathrm{HD}$ bands were produced in the severely bleached colonies that did not complete gametogenesis that year. The formation of HD bands only in colonies which bleached but were still able to reproduce (even though all the study's colonies experienced the same environmental conditions) suggests that the absence of a HD band in 1996 might be related not to bleaching but rather to the lack of gonad development and spawning. Several previous studies have shown an inverse relationship between reproduction and skeletal growth in corals (e.g. Richmond 1987, Babcock 1988, Ward 1995), suggesting that there may be a diversion of energy from skeletal growth to gonad growth during reproductive development. Similar trade-offs between growth and reproduction have also been demonstrated in other marine invertebrates (e.g. Crisp \& Patel 1961, Robinson \& Doyle 1985, Prince et al. 1989).

Acknowledgements. We wish to thank Mr. Bruce Lauckner (Biometrician at the Caribbean Agricultural Research and Development Institute, Trinidad) for assistance with the statistical analyses as well as the anonymous referees for their comments, which improved the manuscript.

\section{LITERATURE CITED}

Babcock RC (1988) Age structure, survivorship and fecundity in populations of massive corals. Proc 6th Int Coral Reef Symp, Australia 2:625-633

Brown BE (1997) Coral bleaching: causes and consequences. Coral Reefs 16:S129-S138

Brown BE, Le Tissier MDA, Bythell JC (1995) Mechanisms of bleaching deduced from histological studies of reef corals sampled during a natural bleaching event. Mar Biol 122: 655-663

Coles SL, Jokiel PL (1978) Synergistic effects of temperature, salinity and light on the hermatypic coral Montipora verrucosa. Mar Biol 49:187-195

Crisp DJ, Patel B (1961) The interaction between breeding and growth rate in the barnacle Elminius modestus Darwin. Limnol Oceanogr 6(2):105-115

Dodge RE, Szmant AM, Garcia R, Swart PK, Forester A, Leder JJ (1992) Skeletal structural basis of density banding in the reef coral Montastræa annularis. Proc 7th Int Coral Reef Symp, Guam 1:186-195

Edmunds PJ, Spencer Davies P (1986) An energy budget for Porites porites (Scleractinia). Mar Biol 92:339-347

Fitt WK, Warner ME (1995) Bleaching patterns of four species of Caribbean reef corals. Biol Bull 189:298-307

Fitt WK, Spero HJ, Halas J, White MW, Porter JW (1993) Recovery of the coral Montastrea annularis in the Florida
Keys after the 1987 Caribbean 'bleaching event'. Coral Reefs 12(2):57-64

Fitt WK, McFarland FK, Warner ME, Chilcoat GC (2000) Seasonal patterns of tissue biomass and densities of symbiotic dinoflagellates in reef coral and relation to coral bleaching. Limnol Oceanogr 45(3):667-685

Gates RD, Baghdasarian G, Muscatine L (1992) Temperature stress causes host cell detachment in symbiotic cnidarians: implications for coral bleaching. Biol Bull 182: $324-332$

Glynn PW (1993) Coral reef bleaching: ecological perspectives. Coral Reefs 12:1-17

Glynn PW, Perez M, Gilchrist SL (1985) Lipid decline in stressed corals and their crustacean symbionts. Biol Bull 168:276-284

Goreau TJ, Macfarlane AH (1990) Reduced growth rate of Montastrea annularis following the 1987-1988 coral bleaching event. Coral Reefs 8:211-215

Guzman HM, Holst I (1993) Effects of chronic oil-sediment pollution on the reproduction of the Caribbean reef coral Siderastrea siderea. Mar Pollut Bull 26(5):276-282

Guzman HM, Tudhope AW (1998) Seasonal variation in the skeletal extension rate and stable isotopic $\left({ }^{13} \mathrm{C} /{ }^{12} \mathrm{C}\right.$ and ${ }^{18} \mathrm{O} /{ }^{16} \mathrm{O}$ ) composition in response to several environmental variables in the Caribbean reef coral Siderastrea siderea. Mar Ecol Prog Ser 166:109-118

Hayes RL, Bush PG (1990) Microscopic observations of recovery in the reef-building scleractinian coral, Montastrea annularis, after bleaching on a Cayman reef. Coral Reefs 8:203-209

Hoegh-Guldberg O, Smith JG (1989) The effect of sudden changes in temperature, light and salinity of the population density and export of zooxanthellae from the reef corals Stylophora pistillata (Esper) and Seriatopora hystrix (Dana). J Exp Mar Biol Ecol 129:279-303

Huppert A, Stone L (1998) Chaos in the Pacific's coral reef bleaching cycle. Am Nat 152:447-459

Jokiel PL, Coles SL (1977) Effects of temperature on the mortality and growth of Hawaiian reef corals. Mar Biol 43: 201-208

Kushmaro A, Loya Y, Fine M, Rosenberg E (1996) Bacterial infection and coral bleaching. Nature 380:396

Lamberts AE (1978) Coral growth: Alizarin method. In: Stoddart DR, Johannes RE (eds) Coral reefs: research methods. UNESCO, Paris, p 523-527

Leder JJ, Szmant AM, Swart PK (1991) The effect of prolonged 'bleaching' on skeletal banding and stable isotopic composition in Montastrea annularis. Coral Reefs 10: $19-27$

Le Tissier MDA, Brown BE (1996) Dynamics of solar bleaching in the intertidal reef coral Goniastrea aspera at Ko Phuket, Thailand. Mar Ecol Prog Ser 136:235-244

Lough JM, Barnes DJ (2000) Environmental controls on growth of the massive coral Porites. J Exp Mar Biol Ecol 245:225-243

Luna JG (1968) Manual of histologic staining methods of the Armed Forces Institute of Pathology, 3rd edn. McGrawHill, New York

Mendes JM (2002) Skeletal density banding in the stony coral Montastraea annularis. PhD thesis, University of the West Indies, Mona, Jamaica, p 129

Mendes JM, Woodley JD (2002) Timing of reproduction in Montastraea annularis: relationship to environmental parameters. Mar Ecol Prog Ser 227:241-251

Muscatine L (1967) Glycerol excretion by symbiotic algae from corals and Tridacna and its control by the host. Science 156:516-519 
Muscatine L, Falkowski PG, Porter JW, Dubinsky Z (1984) Fate of photosynthetic fixed carbon in light and shadeadapted colonies of the symbiotic coral Stylophora pistillata. Proc R Soc Lond B 222:181-202

Ogden J, Wicklund R (1988) Mass bleaching of coral reefs in the Caribbean: a research strategy. National Undersea Research Program Research Report 88-2

Porter JW, Fitt WK, Spero HJ, Rogers CS, White MW (1989) Bleaching in reef corals: physiological and stable isotope response. Proc Natl Acad Sci USA 86:9342-9346

Prince JD, Sellers TL, Ford WB, Talbot SR (1989) Recruitment, growth, mortality and population structure in a southern Australian population of Haliotis rubra (Mollusca: Gastropoda). Mar Biol 100:75-82

Richmond RH (1987) Energetic relationships and biogeographical differences among fecundity, growth and reproduction in the reef coral Pocillopora damicornis. Bull Mar Sci 41(2):594-604

Robinson BW, Doyle RW (1985) Tradeoff between male repro-

Editorial responsibility: Otto Kinne (Editor),

Oldendorf/Luhe, Germany duction (amplexus) and growth in the amphipod Gammarus lawrencianus. Biol Bull 168:482-488

Scoffin TP, Tudhope AW, Brown BE, Chansang H, Cheeney RF (1992) Patterns and possible environmental controls of skeletogenesis of Porites lutea, South Thailand. Coral Reefs 11:1-11

Szmant AM, Gassman NJ (1990) The effects of prolonged 'bleaching' on the tissue biomass and reproduction of the reef coral Montastraea annularis. Coral Reefs 8:217-224

Tudhope AW, Allison N, Le Tissier MDA, Scoffin TP (1992) Growth characteristics and susceptibility to bleaching in massive Porites corals, South Thailand. Proc 7th Int Coral Reef Symp 1:64-69

Ward S (1995) Two patterns of energy allocation for growth, reproduction and lipid storage in the scleractinian coral Pocillopora damicornis. Coral Reefs 14(2):87-90

Williams EH, Bunkley-Williams L (1990) The world-wide coral reef bleaching cycle and related sources of coral mortality. Atoll Res Bull 335:1-71

Submitted: August 1, 2001; Accepted: February 7, 2002 Proofs received from author(s): May 17, 2002 